Article

\title{
Improving the GIS-DRP Approach by Means of Delineating Runoff Characteristics with New Discharge Relevant Parameters
}

\author{
Marco Hümann ${ }^{1} *$ and Christoph Müller ${ }^{1,2}$ \\ 1 Department of Soil Science, University Trier, 54286 Trier, Germany \\ 2 Department of Geography, University of Koblenz-Landau, 56070 Koblenz, Germany; \\ E-Mail: chmueller@uni-koblenz.de \\ * Author to whom correspondence should be addressed; E-Mail: m.huemann@gmx.de; \\ Tel.: +49-651-201-2242; Fax: +49-651-201-3809.
}

Received: 6 December 2012; in revised form: 15 January 2013 / Accepted: 22 January 2013 / Published: 31 January 2013

\begin{abstract}
At present it is common to use geographic information system (GIS) applications to assess runoff generation. One of these GIS-based tools to generate maps of dominant runoff processes is the so called GIS-DRP approach. The tool, which has been developed mainly based on agricultural areas, uses commonly available input data like a digital elevation model (DEM), geological information as well as land use information. The aim of this study is to test, validate and improve this GIS-DRP method for forested and silviculture areas. Hence, soil-hydrologic investigations and several mapping techniques of dominant runoff processes were conducted on 25 test-plots in four forested catchments in Rhineland-Palatinate (Germany) and the Grand Duchy of Luxembourg. By comparing the results of the mapping techniques and those of the test plots, weak points in the original GIS-DRP method were detected. Subsequently, it was possible to enhance the GIS-DRP approach by incorporating new discharge relevant parameters like topsoil sealing, extreme weather events and semipermeability of the substratum. Moreover, the improved GIS-DRP approach can be widely used in different landscapes and for different fields of application. The adapted method can now support foresters and decision makers in forestry planning, answer questions concerning the landscape water balance and peripheral water retention or provide extra information for sustainable forest planning in times of a changing climate.
\end{abstract}


Keywords: GIS approach; runoff generation; dominant runoff processes; soil-hydrology

\section{Introduction \& Aim}

It is expected that global climate change will influence the water balance in Rhineland-Palatinate (Southwest Germany) due to modified temperatures and precipitation distribution (Grigoryan et al. [1] (p. 1) and Casper et al. [2]). Therefore, the knowledge of runoff generation as well as dominant runoff processes (DRP) and their spatial distribution in a catchment or landscape is very important regarding the hydrological behavior of multi-scale catchments, landscape water regimes and flood precaution. In this context [1,3], detailed information about dominant runoff processes can support precautionary measures within suitable areas and helps to implement expert knowledge into a sustainable landscape management. Field investigations to characterize DRPs are the best method to investigate and analyze soil-hydrological parameters and dominant runoff processes in detail. Unfortunately, auger driven mapping and other field investigations are very labor and cost intensive. Therefore, nowadays, it is common to use different kinds of hydrologic models or GIS applications to simulate runoff generation [4]. Several GIS-based methods to identify runoff processes, ranging from the plot scale to the meso-scale were developed over the past years (e.g., [5-13]). However, most of the existing approaches refer only to micro-scale catchments and are based on very detailed geo-data (e.g., soil-maps 1:5,000, landscape mappings, forest site mappings etc.). This makes a regionalization and an appliance in unmapped geographical regions very challenging. For that reason Müller et al. [14] developed a GIS-based approach to identify and regionalize dominant runoff processes in the landscape (GIS-DRP) by using commonly available geo-data. Intersecting a DEM (spatial resolution $5 \mathrm{~m} \times 5 \mathrm{~m}$ to $20 \mathrm{~m} \times 20 \mathrm{~m}$ ), digital geological maps $(1: 200,000)$ as well as land use information (ATKIS, Amtlich Topographisch-Kartographisches Informationssystem; Germany), establishes maps of DRP and their spatial distribution. The GIS-DRP maps are able (i) to identify flood-contributing areas; (ii) to serve as input for hydrological models; (iii) to identify areas for possible water retention, and furthermore, they give supporting information regarding planning and management of catchments. Nevertheless, this application has been developed mainly based on agricultural areas. Due to the versatility of the method, it is of great interest to apply this method to areas of predominant forest use in order to test its accuracy under different land use types and develop adaptations accordingly to the results.

The objective of the presented study is to validate and improve the GIS-DRP method; especially in predominantly silviculturally used catchments. The approach should be able to cover dominant runoff processes during different types of precipitation intensities in all kinds of land use. As a basis for validation, soil-hydrological investigation and mapping of dominant runoff processes were accomplished in four test sites in Rhineland-Palatinate (Germany) and the Grand Duchy of Luxembourg. Sprinkling experiments, infiltration experiments and soil physical investigations were applied on plot- and point-scale, in order to validate the generated GIS-DRP maps. A field mapping approach based on Scherrer [5] made it possible to validate and compare results even further. 


\section{Study Area}

The soil-hydrological investigation and DRP mapping took place in four catchments, which are situated in the German federal state of Rhineland-Palatinate (Frankelbach and Holzbach) and in the Grand Duchy of Luxembourg (Weierbach and Huewelerbach). In total, 25 test plots were surveyed. All test plots within the catchments are forested, except for one arable field site at the Frankelbach catchment, which has been included for comparison. Each plot represents a typical part of the catchment, and it is assumed that all test plots combined represent the overall basin characteristics [15]. Another selection criterion was the accessibility of the test plots in order to conduct the very labor-intensive experiments in the best possible way. The natural characteristics and the location of the different catchments are given in Table 1 and Figure 1. The locations of the plots are shown in the GIS-DRP maps within the results section.

Several different geologic parent materials as well as different landscapes, which are present in the study area, made it possible to cover a wide range of soil types and forest conditions.

Table 1. Basic characteristics of the ForeStClim test sites in Rhineland-Palatinate and Luxembourg.

\begin{tabular}{|c|c|c|c|c|}
\hline & $\begin{array}{c}\text { Frankelbach } \\
\text { (FRA1-FRA7) }\end{array}$ & $\begin{array}{c}\text { Holzbach } \\
\text { (HOL1-HOL6) } \\
\end{array}$ & $\begin{array}{c}\text { Weierbach } \\
\text { (WEI1-WEI8) }\end{array}$ & $\begin{array}{l}\text { Huewelerbach } \\
\text { (HUE1-HUE4) }\end{array}$ \\
\hline $\begin{array}{c}\text { Geographic } \\
\text { area }\end{array}$ & $\begin{array}{c}\text { Saar-Nahe Bergland } \\
\text { (RLP) }\end{array}$ & $\begin{array}{l}\text { Hoch-Idarwald, } \\
\text { Hunsrück (RLP) }\end{array}$ & $\begin{array}{c}\text { Oesling } \\
\text { (Luxembourg) }\end{array}$ & $\begin{array}{c}\text { Gutland } \\
\text { (Luxembourg) }\end{array}$ \\
\hline $\begin{array}{c}\text { Catchment } \\
\text { area }\end{array}$ & $5 \mathrm{~km}^{2}$ & $4.2 \mathrm{~km}^{2}$ & $0.4 \mathrm{~km}^{2}$ & $2.7 \mathrm{~km}^{2}$ \\
\hline $\begin{array}{l}\text { Average } \\
\text { elevation } \\
\text { (AMSL) }\end{array}$ & $210-430 \mathrm{~m}$ & $400-650 \mathrm{~m}$ & $480-520 \mathrm{~m}$ & $300-400 \mathrm{~m}$ \\
\hline $\begin{array}{l}\text { Temperature } \\
\text { (annual ) }\end{array}$ & $9^{\circ} \mathrm{C}$ & $8^{\circ} \mathrm{C}$ & $8^{\circ} \mathrm{C}$ & $9^{\circ} \mathrm{C}$ \\
\hline $\begin{array}{l}\text { Precipitation } \\
\text { (annual) }\end{array}$ & $700-800 \mathrm{~mm}$ & $950-1,200 \mathrm{~mm}$ & $900-1,100 \mathrm{~mm}$ & $750-850 \mathrm{~mm}$ \\
\hline Land use & $\begin{array}{l}30 \% \text { forest, } 70 \% \\
\text { pasture/arable land }\end{array}$ & $100 \%$ forest & $100 \%$ forest & $\begin{array}{c}91 \% \text { forest, } \\
7 \% \text { pasture land, } \\
2 \% \text { settlement area }\end{array}$ \\
\hline $\begin{array}{l}\text { Parent } \\
\text { material }\end{array}$ & $\begin{array}{c}\text { Permian } \\
\text { "Rotliegendes" New } \\
\text { Red sediments }\end{array}$ & Devonian quartzite & $\begin{array}{l}\text { Devonian schist } \\
\text { "Sergean group" }\end{array}$ & $\begin{array}{c}\text { Permian Sandstone } \\
\text { and Marls }\end{array}$ \\
\hline $\begin{array}{l}\text { Dominant } \\
\text { soil types }\end{array}$ & $\begin{array}{c}\text { Haplic/Stagnic } \\
\text { Cambisols }\end{array}$ & $\begin{array}{l}\text { Haplic/Stagnic } \\
\text { Cambisols and } \\
\text { Podzols }\end{array}$ & Haplic Cambisols & $\begin{array}{l}\text { Regosols, Haplic } \\
\text { Cambisols, Podzols }\end{array}$ \\
\hline $\begin{array}{l}\text { Number of } \\
\text { test plots }\end{array}$ & 7 & 6 & 8 & 4 \\
\hline
\end{tabular}


Figure 1. Location of the ForeStClim test sites in Rhineland-Palatinate and Luxemburg (http://www.mygeo.info); FRA = Frankelbach, HOL = Holzbach, HUE = Huewelerbach, WEI $=$ Weierbach .
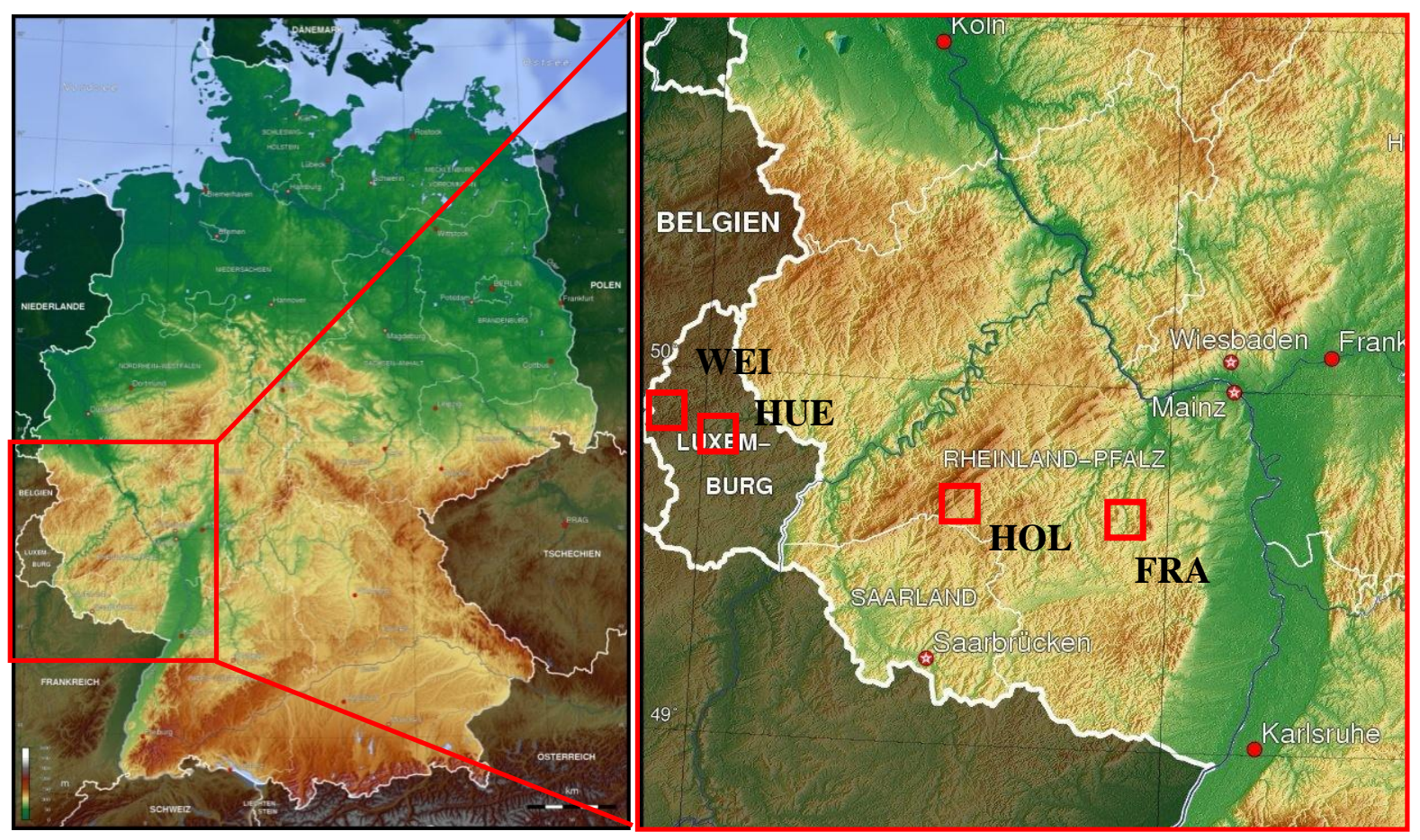

During the Pleistocene, periglacial solifluidal processes were common in the low mountain ranges of Southwest Germany and the adjacent states [15]. Therefore, many soil profiles within the test sites are characterized by a densely stratified "basal layer" in the subsoil and a loose and permeable "main layer" in the topsoil [16-18]. This soil build-up has a major influence on discharge generation and dominant runoff processes in a catchment since it abets mainly subsurface flow processes of different reaction velocities. Nevertheless, all kinds of DRP (surface and subsurface flow types) could be determined during the soil-hydrological field campaigns, showing a high overall heterogeneity of the forested plots.

\section{Methods}

\subsection{DRP Approaches}

\section{Process Decision Schemes}

Based on a large number of field experiments Scherrer [5] and Scherrer \& Naef [8] developed so-called process decision schemes (PBS), to determine dominant runoff processes on a soil profile. The mentioned approach was developed and applied effectively in Switzerland [8,9]. Generally, this method integrates climatic and physiographic characteristics $[5,9,10,19]$. The methodology uses as main parameters: land use, vegetation, soil, relief and geology $[5,8,9,20]$. The processes that can be estimated by these process decision schemes are Hortonian Overland Flow (HOF 1, 2), Saturated Overland Flow (SOF 1, 2, 3), Subsurface Flow (SSF 1, 2, 3) and Deep Percolation (DP), and typically 
occur after prolonged rainfall events (Figure 2). The numbers in the abbreviations reflect the velocity of the discharge process, i.e., 1 stands for a fast, 2 for an intermediate and 3 for a delayed processes. The subdivision of the decision schemes depends on land use types (arable land, grassland, forest and vineyards), slope $(20 \%<\mathrm{S}>3 \%$ and $\mathrm{S}>3 \%, \mathrm{~S}>5 \%$ for vineyard), precipitation intensity $\left(\mathrm{I}<20 \mathrm{~mm} \cdot \mathrm{h}^{-1} ; \mathrm{I}>20 \mathrm{~mm} \cdot \mathrm{h}^{-1}\right.$ ) and soil characteristics (soils with non-stagnic characteristics and soils with stagnic characteristics). Hence, nine process decision schemes are available to identify the DRP of a certain plot [8].

Figure 2. Dominant Runoff Processes (DRP) on a slope (Scherrer [5] and * Schüler [6], modified).

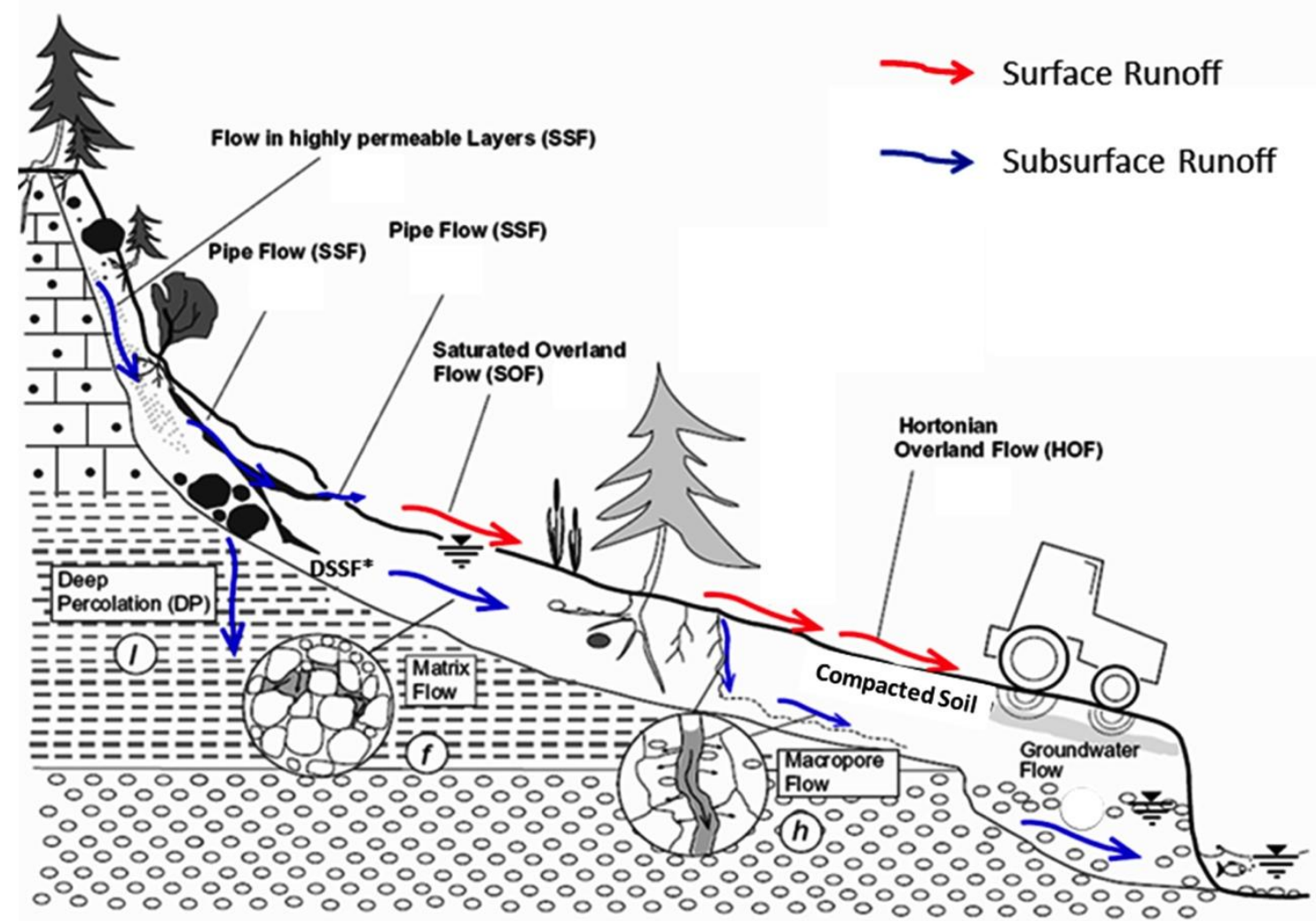

\section{GIS-DRP}

As a simplification of the method based on Scherrer [5] the GIS-DRP-tool developed by Müller et al. [14] combines an analysis of the topography, the geologic information and the land use varieties. Maps of dominant runoff processes are thus created without the necessity of using detailed soil maps or other geo-information, which is often not available. GIS-DRP requires a DEM, a geological map and the land use information as data input [14]. Although the results of Müller et al. [14] indicate an $80 \%$ match, they still advise the user to validate the GIS-DRP results with a mapping campaign to improve the outcomes of the mapping exercise.

The method of Müller et al. [14] can be described as follows: In a first step, the slopes are calculated and classified with a DEM. Secondly, the geological substrata of the basins are classified. This substrata classification is based on Zumstein et al. [21] who classified the infiltration permeability of the substratum with respect to its lithology and geo-hydrological characteristics such as fractures 
and porosity obtaining eight different permeability classes. Müller et al. [14] modified this classification of Zumstein et al. [21]. Moreover, some exceptions were made based on field studies accomplished by Hümann et al. [15], e.g., the Triassic sediment Buntsandstein (lower Triassic) is divided into three main ages. The Buntsandstein in general is classified as permeable ([21], predominantly sandy substrates). However, due the field experience of Hümann et al. [15], the uppermost Buntsandstein layer (clayey weathering) is classified as impermeable.

In a third step, the preprocessed digital data is intersected, which result in maps that display dominant runoff processes (DRP). The assumed DRP dependency for arable land, grassland and forest, is given in Table 2 and serves as a basis for intersecting the data and identifying the DRP for every polygon. The nomenclature of the several discharge processes is correspondingly based on the process decision schemes of Scherrer [5].

Table 2. Geographic information system-dominant runoff processes (GIS-DRP) basic table; DRP regarding the slope, the geological substratum and the land use (based on Müller et al. [14], modified).

\begin{tabular}{cccc}
\hline $\begin{array}{c}\text { Slope } \\
(\%)\end{array}$ & $\begin{array}{c}\text { Impermeable } \\
\text { Arable Land + Grassland }\end{array}$ & $\begin{array}{c}\text { Impermeable } \\
\text { Forest }\end{array}$ & $\begin{array}{c}\text { Permeable } \\
\text { Arable Land + Grassland + Forest }\end{array}$ \\
\hline $0-3 *$ & SOF 3 & SOF 3 & DP \\
$>3-5 *$ & SOF 2 & SSF 3 & DP \\
$>5-20 *$ & SSF 2 & SSF 2 & DP \\
$>20-40 * *$ & SSF 1 & SSF 2 & DP \\
$>40 * *$ & SSF 1 & SSF 1 & DP \\
\hline
\end{tabular}

* based on Scherrer [5], partly modified; ** based on Scherrer [5] and Schüler [6], partly modified.

Besides these previously defined criteria, a few additional assumptions are applied in the analysis [20] (p. 108), urban areas tend to produce Hortonian overland flow (HOF) due to large areas of sealed surfaces. Secondly, the riparian zone is represented by areas of fast reacting saturated overland flow (SOF 1) on both sides of the stream network. The size of this so-called "buffer" depends proportionally on the width of the stream channel and the steepness of the neighboring slopes. In general GIS-DRP includes moderate rainfall intensities and high degrees of vegetation cover protecting the soil surface from immediate rain and wind impact. So far, GIS-DRP covers the following five "event classes" based on precipitation intensity, season and degree of coverage:

I. Short intensive rainfall in summer ( $>50 \%$ vegetation coverage)

II. Long lasting extensive rainfall in summer ( $>50 \%$ vegetation coverage)

III. Short intensive rainfall in winter $(>50 \%$ vegetation coverage)

IV. Long lasting extensive rainfall in winter ( $>50 \%$ vegetation coverage)

V. Long lasting extensive rainfall in winter $(<50 \%$ vegetation coverage $)$

However, the method was mainly developed in agriculturally used areas. Its application in mostly forested regions implies a certain error potential, since the general interaction between forest, soil and water in silviculture-used areas is very complex. Also, not every possible event class (five out of eight, see below) can be covered by the basic GIS-DRP approach and it is mandatory to validate the GIS-DRP maps in areas that are predominantly forested. Comparing these DRP maps with results of 
soil-hydrological fieldwork and other DRP-classification approaches achieves this. Only a validation of the discharge process maps created by GIS-DRP can ensure the accuracy of the tool regarding reliable and realistic results and possible sources of error.

\subsection{Soil-Hydrological Investigations}

\section{Soil Physical Investigations}

Undisturbed samples ( $\mathrm{V}=100 \mathrm{~cm}^{3} ; \mathrm{n}=6$ per horizon) were taken from every soil horizon $(\mathrm{n}=105)$ from every soil pit ( $n=25$; in accordance with the number of plots) to determine the soil physical properties of the different plots. In the laboratory, the parameters bulk density, total pore volume and pore size distribution, penetration resistance, air conductivity as well as saturated water conductivity were determined. These results were used to interpret the soil build-up and compared with the results of the sprinkling and infiltration experiments, respectively, to check the plausibility of the accomplished mappings.

\section{Sprinkling Experiments at the Plot-Scale $\left(50 \mathrm{~m}^{2}\right)$}

The setup of the plot-scale sprinkling experiment followed that of Hümann et al. [15], Müller [22] and Schobel [23] and is based on the concept of Karl \& Toldrian [24]. This very labor-intensive method allows the simulation of realistic rainfall events with intensities of $40 \mathrm{~mm} \cdot \mathrm{m}^{-2} \cdot \mathrm{h}^{-1}$. Moreover, the artificial rainfall was distributed over three consecutive days with a total precipitation amount of $120 \mathrm{~mm}$. The rainfall amount and its distribution over three days are based on a flood event in the Rhine catchment in March 2001 [25]. The execution of one sprinkling experiment takes five to six days in total including the installation of the equipment, the sprinkling itself and the subsequent runoff measurements. To assure comparability and because interception is hardly of any relevance if it comes to storm rainfalls or long lasting precipitation in moist winter periods (see above), the sprinkling experiments were carried out beneath the crown canopy of the forest stands [15] (p. 642). One major advantage of this method is that different runoff processes can directly be observed and measured. Another advantage is given because of the mobility of the experimental setup, which makes it possible to compare results from different catchments or landscapes. The rainfall simulator consists of a U-shaped pipe system with an irrigated area of approximately $50 \mathrm{~m}^{2}(5 \mathrm{~m} \times 10 \mathrm{~m}$; Figure 3$)$. The amount of the overhead irrigation during the experiments as well as the distribution was recorded with three soil-based Hellmann and six rain gauges within the irrigated area [22]. Directly at the down-slope edge of the irrigated area a $3 \mathrm{~m}$ wide soil pit was set up. The width of the pit was smaller than the width of the irrigated area. An area of $1 \mathrm{~m}$ at each side functioned as a drainage barrier, hindering irrigation water from draining into the neighboring, less irrigated areas. Consequently, the discharge-relevant area at each plot was $30 \mathrm{~m}^{2}(3 \mathrm{~m} \times 10 \mathrm{~m})$. Deflector plates inserted into the soil profile at different depths were used to separately quantify surface and subsurface flow. For each identified soil layer, the beveled-edge plates collected the water flow and redirected it into a measuring vessel. The surface flow plates were inserted close to the soil surface; subsurface and deep subsurface flow were recorded in two different depths: one in an upper, loosely stratified, soil horizon and one just below the border to the deeper, compacted basal layer [15]. 
Figure 3. Rainfall simulator based on the idea of Karl \& Toldrian [24] at the Holzbach test site with soil pit and collector plates visible in the foreground

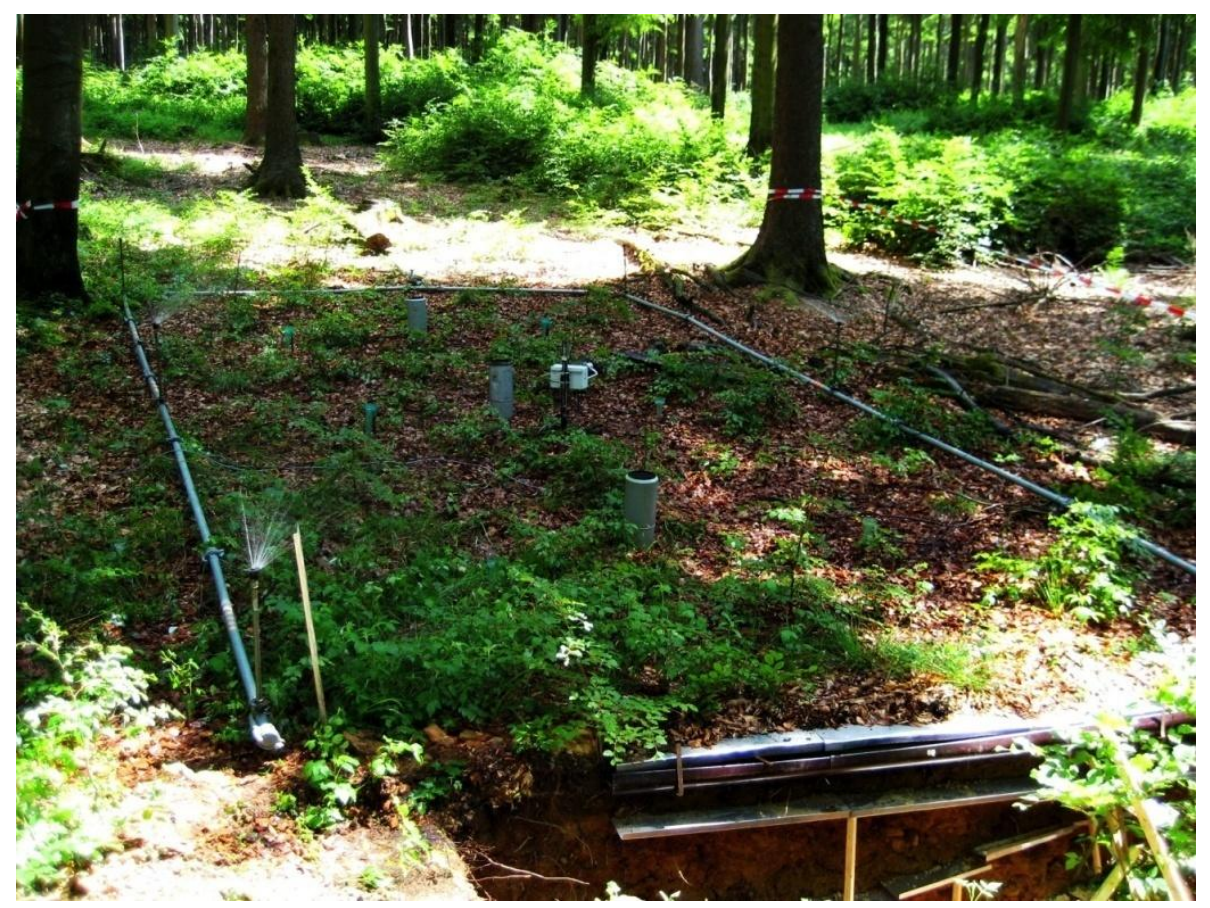

If a surface flow reaction occurred it was either classified as a Hortonian (HOF) type or a saturated type (SOF) by means of visual observation as well as expert judgment [15]. If a subsurface flow reaction occurred, it was classified as SSF 1, SSF 2 or SSF 3, which depended on the reaction velocities and estimated depths of the water flow. If nearly no runoff could be observed, the dominant runoff process was defined as deep subsurface flow (dSSF) or deep percolation (DP), which depended on the prevailing geological substrate [15].

The sprinkling experiments took place in late spring. At that time the soils of the investigated plots were not entirely saturated. Initial soil moisture contents ranged from $61 \%$ to $77 \%$ of field capacity ( $\geq \mathrm{pF}$ 1.8) [15] (p. 642). More detailed information about the applied sprinkling experiments is given in Hümann et al. [15].

\section{Sprinkling Experiments at the Point-Scale $\left(0.28 \mathrm{~m}^{2}\right)$}

Sprinkling experiments on a point-scale were executed (Figure 4) in areas where plot-scale sprinkling experiments were not possible due to a deficient catchment infrastructure or a very permeable parent material (Huewelerbach). The point-scale sprinkling experiment is based on the idea of Calvo et al. [26] and Lasanta et al. [27]. It concentrates on topsoil properties and generation of surface runoff due to sealing and crusting or hydrophobic effects evoked by e.g., longer drought periods. Here, one nozzle, which is built in an aluminum frame that is $2 \mathrm{~m}$ high, realizes a rainfall intensity of $40 \mathrm{~mm} \cdot \mathrm{h}^{-1}$. Surface runoff is collected in five-minute intervals. Afterwards, the water amount and sediment yield can be estimated in the laboratory. More detailed information about the setup and handling of this kind of rainfall simulator is given in, e.g., Iserloh et al. [28]. 
Figure 4. Small portable rainfall simulator with water tank-pump combination (yellow; foreground) and nozzle-linkage-tarpaulin system (green).

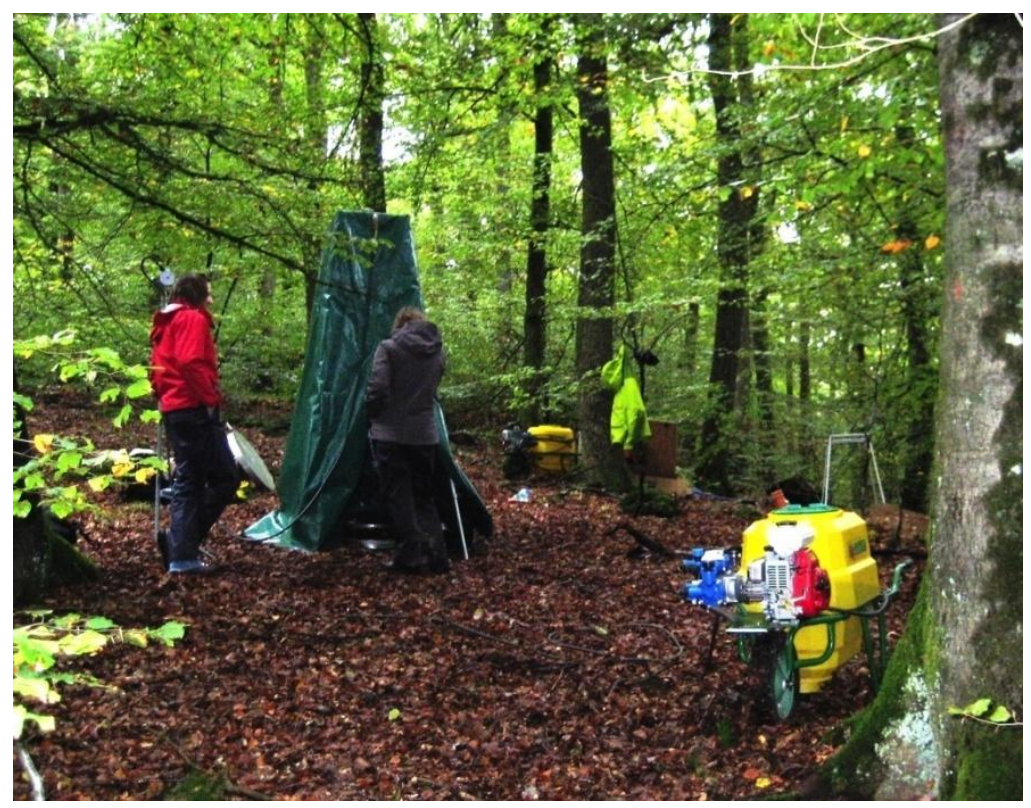

\section{Infiltration Experiments}

To determine the infiltration rates of the test sites and plots, infiltration experiments with a double ring-infiltrometer (type according to a DIN-infiltrometer) were conducted (Figure 5). At one plot, at least four infiltration experiments took place $\left(\sum=116\right)$. The categorization of Wohlrab et al. [29] classifies the resulting infiltration rates.

Figure 5. Double-ring infiltrometer during a measurement.

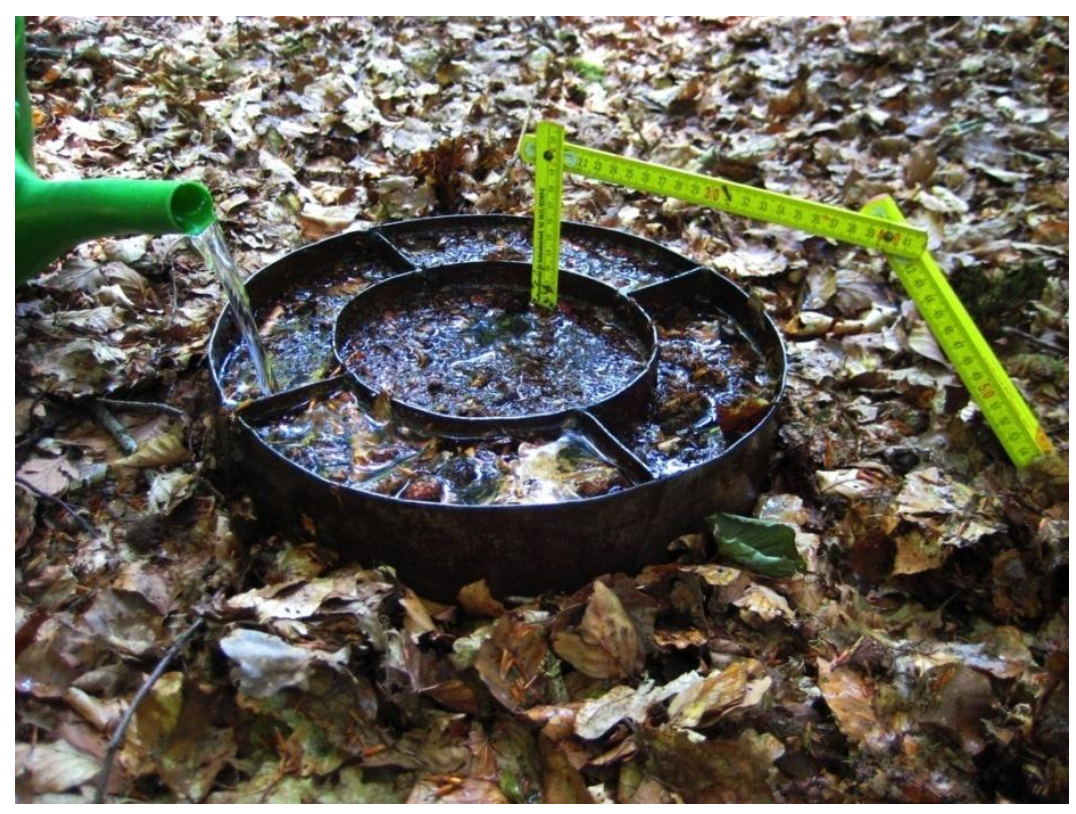




\section{Results}

\subsection{Application \& Validation}

The GIS-DRP application resulted in four runoff process maps, which show the dominant runoff processes and their spatial distribution within the investigated basins (Figures 6-9). Three of these GIS-DRP maps (Frankelbach, Holzbach and Weierbach) are dominated by subsurface flow processes of different reaction velocities (73\% of SSF 1 to $95 \%$ of SSF 3). In contrast, the Huewelerbach catchment is dominated by deep percolation (DP), which is represented by a light blue color (62\% of the total area). Generally, the stream network is surrounded by red colored areas. These riparian zones (especially their width) depend on the adjacent relief. The riparian zones (so-called "buffer" zones) tend to produce fast reacting saturated overland flow (SOF 1; up to $15 \%$ for the investigated catchments). The road network and settlement areas produce Hortonian overland flow (HOF, purple) due to sealed soil surfaces. Small areas at the catchment boarders are colored in beige or orange showing delayed saturated overland flow processes (SOF 2 and SOF 3) due to moderately declining slopes.

Figure 6. GIS-DRP map of the Frankelbach catchment, Rhineland-Palatinate (error = lack of basic data).

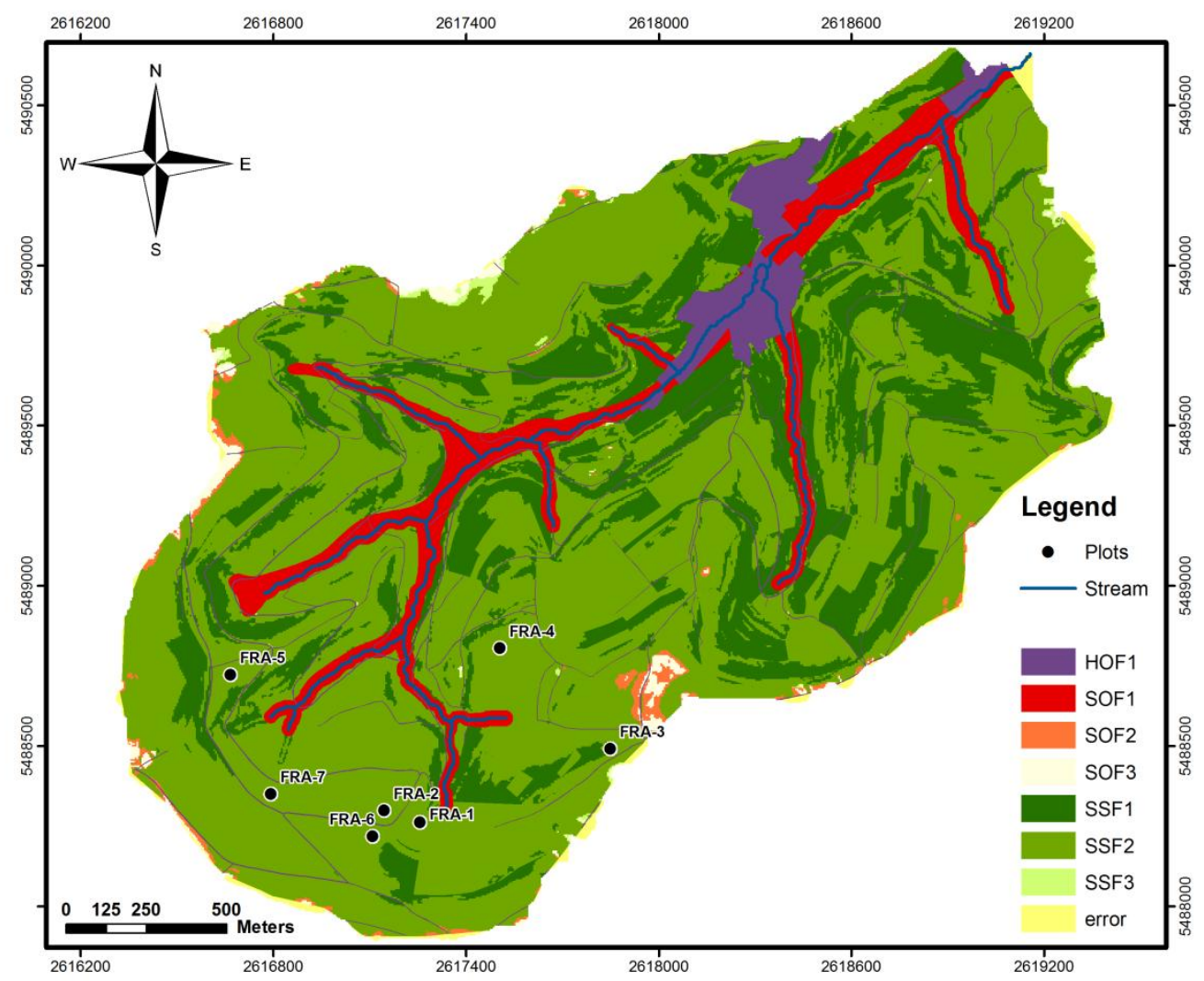


Figure 7. GIS-DRP map of the Holzbach catchment, Rhineland-Palatinate (error = lack of basic data).

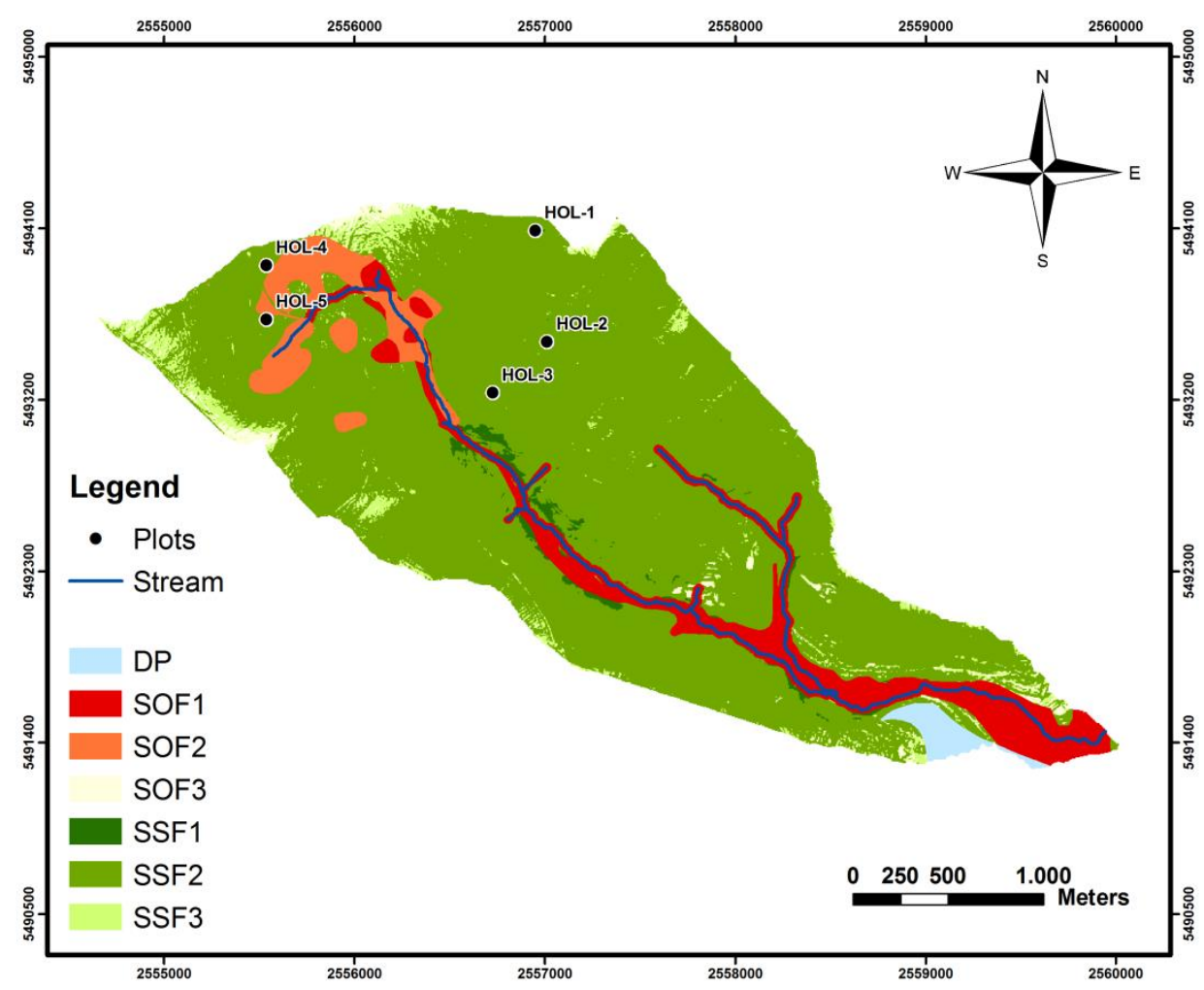

Figure 8. GIS-DRP map of the Weierbach catchment, Luxembourg.

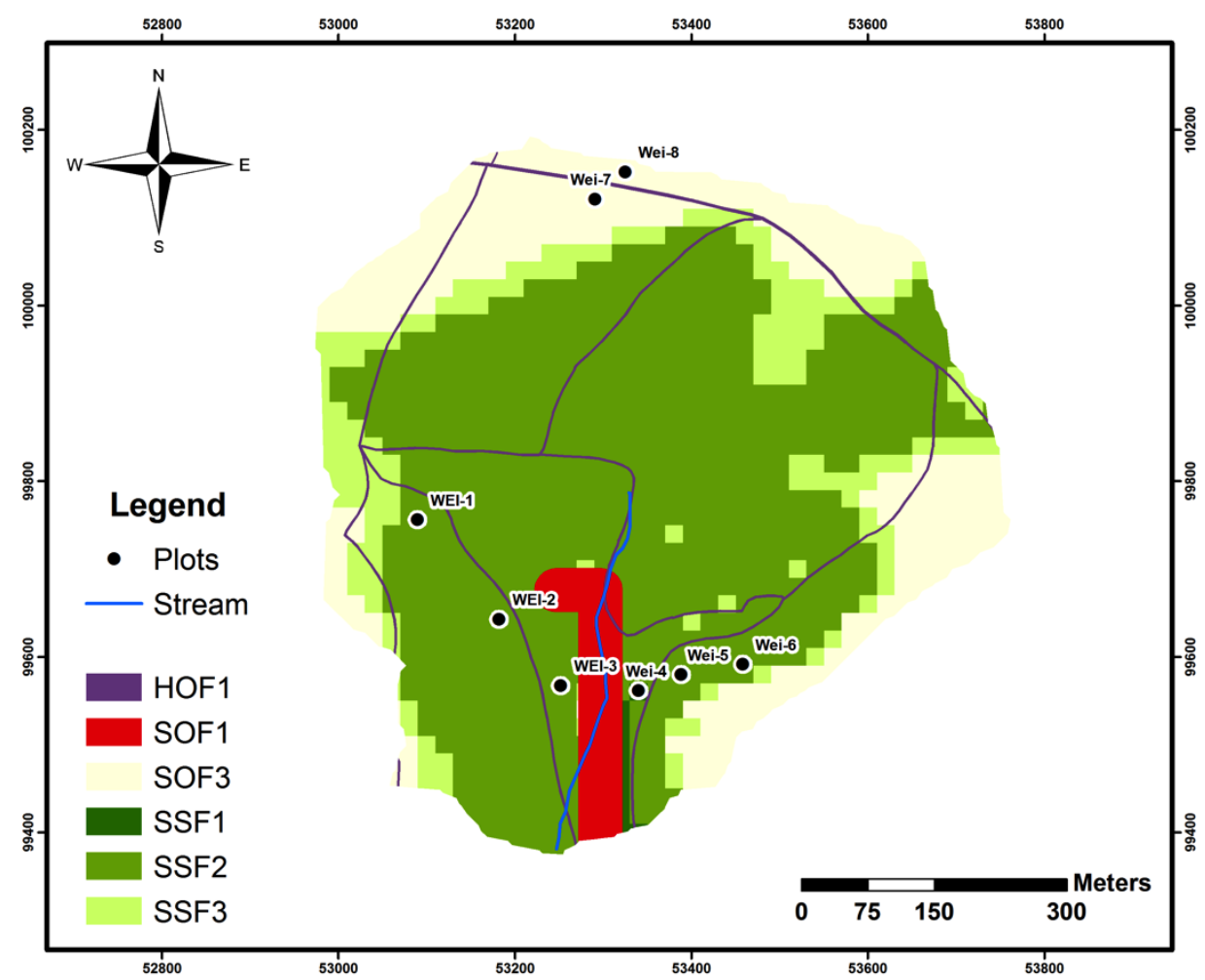


Figure 9. GIS-DRP map of the Huewelerbach catchment, Luxembourg (error = lack of basic data).

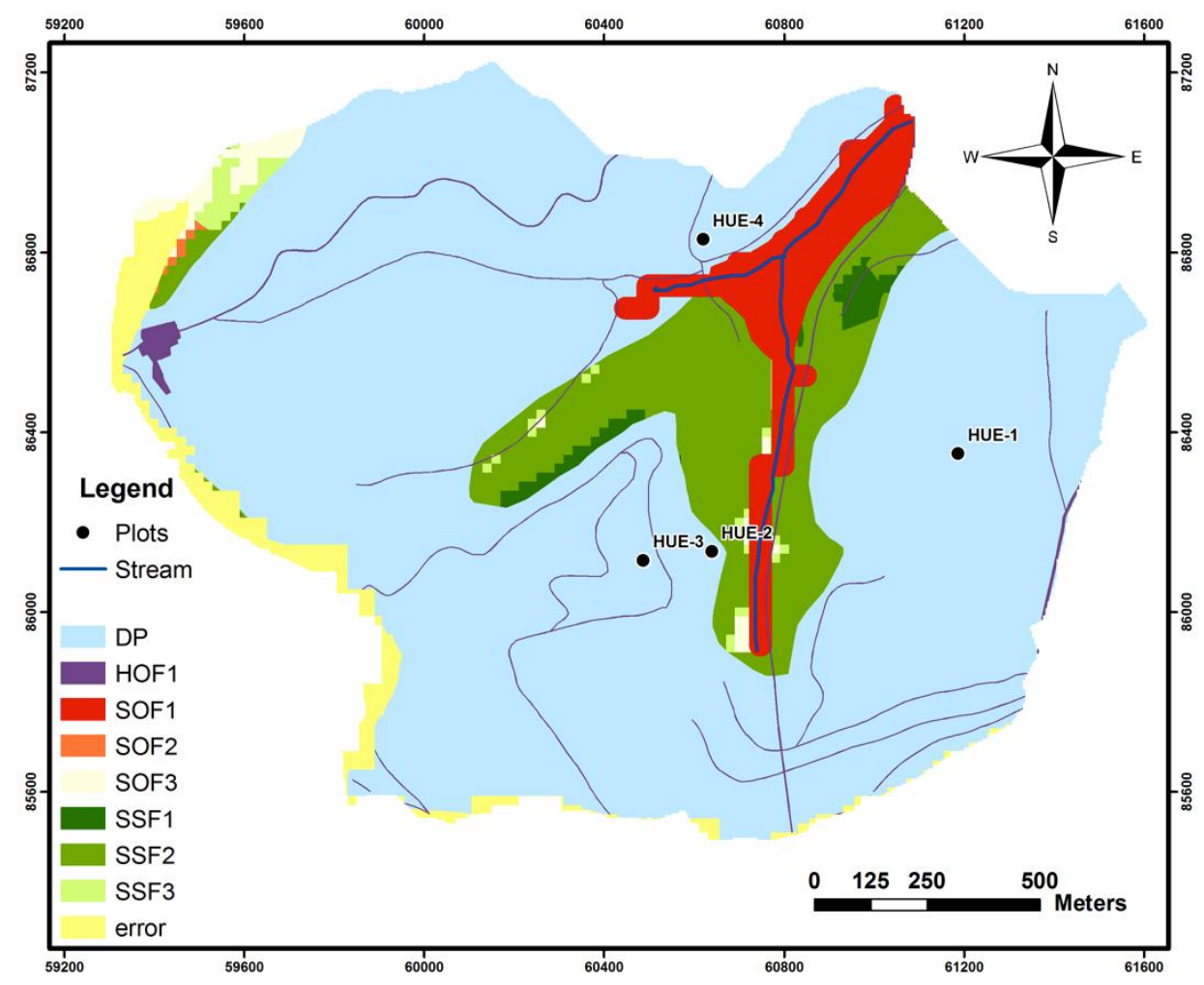

As mentioned before, GIS-DRP was developed on mainly agriculturally used areas. Therefore, the GIS-DRP maps should be validated especially for forested areas by comparing their results with the results of the DRP identification approach (PBS) after Scherrer [5] and the outcomes from the soil-hydrological field investigations accomplished within the four basins. Table 3 lists the several approaches ((i) GIS-DRP; (ii) PBS after Scherrer [5] and (iii) DRP measurements) and their results for all test plots of the catchments (green = matching; yellow = variant; red = not suitable).

Table 3 shows that 18 of the 25 plots predominantly generated subsurface flow processes of different reaction velocities (DRP measurement). This is a typical discharge reaction in forested low mountain ranges within the Renish Slate Mountains (Germany). Here, topsoil layers are mostly loose in structure and topped by organic layers, which protect the soil and improve the infiltration of rainwater. As explained in Section 2 (study area), the wide spread periglacial layers formed a densely stratified basal layer in the subsoil and hinder the percolating water to infiltrate into deeper soil horizons. The vertical water flow transforms into a horizontal one ensuing subsurface flow.

The differing measurements in the Frankelbach catchment (FRA) can be explained due to a very heterogeneous parent material (Permian Rotliegendes, New Red Sandstone) as well as different types of land use and management strategies in that catchment.

In the Huewelerbach catchment (HUE) only deep percolation (DP) was characterized due to the very permeable geologic parent material of the Lias Sandstone (li2). 
Table 3. Comparison of the results from the different DRP identification approaches.

\begin{tabular}{cccc}
\hline Plot & GIS-DRP & $\begin{array}{c}\text { PBS } \\
\text { (Scherrer) }\end{array}$ & $\begin{array}{c}\text { DRP } \\
\text { (Measurement) }\end{array}$ \\
\hline FRA-1 & SSF 2 & SSF 2 & dSSF \\
FRA-2 & SSF 2 & SSF 2 & SSF 1/SOF 2 \\
FRA-3 & SSF 2 & SSF 2 & SSF 2 \\
FRA-4 & SSF 2 & SSF 2 & SSF 2/HOF 1 \\
FRA-5 & SSF 2 & SSF 2 & SSF 2 \\
FRA-6 & SSF 2 & HOF 2 & HOF 2 \\
FRA-7 & SSF 2 & SSF 2 & dSSF \\
\hline HOL-1 & SSF 2 & SSF 3 & SSF 2 \\
HOL-2 & SSF 2 & SSF 3 & SSF 3 \\
HOL-3 & SSF 2 & SSF 2 & SSF 3 \\
HOL-4 & SSF 2 & SSF 2 & dSSF \\
HOL-5 & SSF 2 & SSF 2 & dSSF \\
HOL-6 & SSF 2 & SSF 2 & dSSF \\
\hline WEI-1 & SSF 2 & SSF 2 & dSSF \\
WEI-2 & SSF 2 & SSF 2 & dSSF \\
WEI-3 & SSF 2 & SSF 2 & dSSF \\
WEI-4 & SSF 3 & SSF 3 & dSSF \\
WEI-5 & SSF 2 & SSF 2 & dSSF \\
WEI-6 & SSF 2 & SSF 2 & dSSF \\
WEI-7 & SOF 3 & SOF 3 & SOF 3 \\
WEI-8 & SOF 3 & SOF 3 & SOF 3 \\
\hline HUE-1 & DP & DP & DP \\
HUE-2 & DP & DP & DP \\
HUE-3 & DP & DP & DP \\
HUE-4 & DP & DP & DP \\
\hline & & &
\end{tabular}

The characterized DRP in Table 3 show that the GIS-DRP approach fits rather well with the identification method (PBS) based on Scherrer [5]. The accounted runoff processes differ in only three cases (FRA-6, HOL-1, HOL-2) of the 25 investigated plots. The major difference was determined at the FRA-6 plot. GIS-DRP defines SSF2 (moderate reacting subsurface flow), but the Scherrer-mapping (PBS) results in a HOF 2 process (shortly delayed Hortonian overland flow). This difference occurs because sealing of the topsoil is implemented as a parameter that strongly influences discharge generation in the identification method (PBS) based on Scherrer [5]. Hence, topsoil sealing was identified as additional parameter in order to improve the GIS-DRP method (see Section 4.2(i)).

Besides the identification of soil sealing and the resulting Hortonian overland flow on the agricultural site (FRA-6), varieties of surface runoff (SOF and HOF) were determined even in afforestation (FRA-2, beech and oak) and an established forest (FRA-4, Douglas fir). By conducting sprinkling experiments on plot- and point-scale with high precipitation intensities of $40 \mathrm{~mm} \cdot \mathrm{h}^{-1}$, hydrophobicity of the topsoil (FRA-4, HOF) as well as an impermeable stagnic soil horizon in $15 \mathrm{~cm}$ depth (FRA-2, SOF) were identified as the responsible factors for surface runoff. A predicted accumulation of extreme weather events due to climate change [1,2] made it seem reasonable to implement higher precipitation intensities into GIS-DRP. Thus, different weather conditions could be assessed and runoff reactions during extreme events could be estimated in a more detailed way. As a consequence, the 
implementation of extreme weather events based DRP-maps became the second aim of the following GIS-DRP modification (see Section 4.2(ii)).

Generally, more dissimilarity could be determined when comparing the GIS-DRP results with the outcomes of the measurements of field investigations (Table 3). One of the major reasons is the so-called deeper subsurface flow (dSSF), which is characterized by the soil-hydrological measures. Deeper subsurface flow was introduced by Schüler [6] describing laterally flowing discharge processes within deeper soil horizons or at the soil-bedrock interface named after Tromp-van Meerveld \& McDonnell [30]. The process dSSF was found in three of the four investigated catchments. It occurred due to great soil depths (Frankelbach), impermeable basal layers in the deeper subsoil (Holzbach) or large periglacial layers with very high amounts of coarse soil particles under the subsoil (Weierbach). This parameter is associated with a characterization of the geological substratum as semipermeable. Semipermeability or dSSF processes are implemented neither in GIS-DRP nor within the identification method (PBS) based on Scherrer [5]. This gave reason to incorporate this third new parameter into the GIS-DRP (see Section 4.2(iii)).

\subsection{Improvements}

Summarizing the results of Section 4.1, three parameters have to be added to the GIS-DRP tool to enhance the overall accuracy as well as the spatial distribution of the several dominant runoff processes in a landscape or catchment. They consist of the following:

(i) Topsoil sealing;

(ii) Extreme weather events and

(iii) Semipermeability of the substratum (dSSF).

An adaption of GIS-DRP regarding the three defined parameters is obtained by modifying the GIS-DRP basic table (Table 2), which represents the pivot of the GIS request-algorithm that enables the tool to identify dominant runoff processes.

(i) Topsoil sealing:

The new table regarding topsoil sealing was predominantly changed for impermeable and permeable arable land (Table 4). Further minor modifications concern impermeable grassland and forests. This modification for topsoil sealing similarly encloses an adaption to the event classes. Consequently, the new characterization of DRP covers two so far not implemented classes:

VI. Long lasting extensive rainfall in summer ( $<50 \%$ degree of coverage) and

VII. Short intensive rainfall in winter $(<50 \%$ degree of coverage).

(ii) Extreme weather events:

The results of the adaption of the GIS-DRP basic table regarding the parameter extreme events are listed in Table 5. Almost all DRP on every land use type and every slope became modified, except for forest stands with permeable substrata. Here, no change of characterization is necessary because even in extreme weather events, forests with a highly permeable soil and bedrock tend to produce predominantly deep percolation (DP). In case of grassland usage, mainly saturated overland flow processes (SOF) became classified due to results of field 
studies accomplished by Hümann et al. [15]. Moreover, SOF 2 and SOF 1 were chosen to establish a differentiation between the fast reacting Hortonian overland flow processes (HOF) on urban areas like streets or sealed topsoil surfaces and the slightly delayed SOF processes on grassland. Here, it has to be mentioned that a specific uncertainty remains due to variable surface characteristics on grassland areas (e.g., intensive or extensive grazing; fellow grassland; mowing meadow etc.). These variable surface characteristics cannot definitely be distinguished by the used basic data within the GIS-DRP approach. Thus, the resulting dominant runoff processes on grassland (SOF 1 and SOF 2) during extreme weather events should be seen as an approximation to the actual occurring processes. Nevertheless, with this new classification of dominant runoff processes it was possible to also cover the eighth event class:

VIII. Short intensive rainfall in summer ( $<50 \%$ degree of coverage).

Table 4. GIS-DRP table topsoil sealing.

\begin{tabular}{cccccc}
\hline $\begin{array}{c}\text { Slope } \\
(\%)\end{array}$ & $\begin{array}{c}\text { Impermeable } \\
\text { Arable Land }\end{array}$ & $\begin{array}{c}\text { Impermeable } \\
\text { Grassland }\end{array}$ & $\begin{array}{c}\text { Impermeable } \\
\text { Forest }\end{array}$ & $\begin{array}{c}\text { Permeable } \\
\text { Arable Land }\end{array}$ & $\begin{array}{c}\text { Permeable } \\
\text { Grassland + Forest }\end{array}$ \\
\hline $0-3$ & HOF 2 & SOF 2 & SOF 3 & HOF 2 & DP \\
$3-5$ & HOF 2 & SOF 2 & SSF 3 & HOF 2 & DP \\
$5-20$ & HOF 2 & SSF 1 & SSF 2 & HOF 2 & DP \\
$20-40$ & HOF 2 & SSF 1 & SSF 1 & HOF 2 & DP \\
$>40$ & HOF 2 & SSF 1 & SSF 1 & HOF 2 & DP \\
\hline
\end{tabular}

Table 5. GIS-DRP table extreme events.

\begin{tabular}{ccccccc}
\hline $\begin{array}{c}\text { Slope } \\
(\%)\end{array}$ & $\begin{array}{c}\text { Impermeable } \\
\text { Arable Land }\end{array}$ & $\begin{array}{c}\text { Impermeable } \\
\text { Grassland }\end{array}$ & $\begin{array}{c}\text { Impermeable } \\
\text { Forest }\end{array}$ & $\begin{array}{c}\text { Permeable } \\
\text { Arable Land }\end{array}$ & $\begin{array}{c}\text { Permeable } \\
\text { Grassland }\end{array}$ & $\begin{array}{c}\text { Permeable } \\
\text { Forest }\end{array}$ \\
\hline $0-3$ & HOF 2 & SOF 2 & SOF 2 & HOF 2 & SOF 2 & DP \\
$3-5$ & HOF 2 & SOF 2 & SSF 2 & HOF 2 & SOF 2 & DP \\
$5-20$ & HOF 2 & SOF 2 & SSF 1 & HOF 2 & SOF 2 & DP \\
$20-40$ & HOF 1 & SOF 1 & SSF 1 & HOF 1 & SOF 1 & DP \\
$>40$ & HOF 1 & SOF 1 & SSF 1 & HOF 1 & SOF 1 & DP \\
\hline
\end{tabular}

Accordingly, the five so far enclosed event classes within GIS-DRP (mentioned in Section 3.2) can be classified as relatively low in intensity. Therefore, these rainfall varieties together represent the rainfall intensity class of basic events.

Event classes VI and VII-introduced with the adaption to topsoil sealing-form the rainfall intensity class of medium events.

The event class VIII represents very high precipitation intensities. Hence, this combination of rainfall type, season and degree of coverage characterizes the rainfall intensity class of extreme events.

(iii) Semipermeability:

The parameter semipermeability, which reflects the soil and bedrock characteristics and its permeability for water, is a basic requirement for the generation of deep subsurface flow (dSSF). Since dSSF was determined only on forested plots, this runoff process is associated with forest usage in the modified GIS-DRP table (Table 6). 
Table 6. GIS-DRP table semipermeability.

\begin{tabular}{ccccc}
\hline $\begin{array}{c}\text { Slope } \\
(\%)\end{array}$ & $\begin{array}{c}\text { Impermeable } \\
\text { Arable Land + Grassland }\end{array}$ & $\begin{array}{c}\text { Impermeable } \\
\text { Forest }\end{array}$ & $\begin{array}{c}\text { Semipermeable } \\
\text { Forest }\end{array}$ & $\begin{array}{c}\text { Permeable } \\
\text { Arable Land + Grassland + Forest }\end{array}$ \\
\hline $0-3$ & SOF 3 & SOF 3 & SOF 3 & DP \\
$3-5$ & SOF 2 & SSF 3 & dSSF & DP \\
$5-20$ & SSF 2 & SSF 2 & dSSF & DP \\
$20-40$ & SSF 1 & SSF 2 & dSSF & DP \\
$>40$ & SSF 1 & SSF 1 & dSSF & DP \\
\hline
\end{tabular}

\section{Discussion}

\subsection{Topsoil Sealing}

The so-called Hortonian overland flow (HOF) is one important cause of the direct appearance of overland flow during a rainfall event. Another cause is the sealing and crusting of the topsoil [31] due to splash effects that cause a physical disintegration of soil aggregates [32]. In the latter case a thin sealed soil layer or crust develops, which inhibits water infiltration very efficiently [33]. The renewed GIS-DRP map for the Frankelbach catchment that includes the parameter topsoil sealing, shows a changed runoff process characterization, especially on arable land (Figure 10) where soil sealing is a well-known problem that causes overland flow and erosion.

Figure 10. GIS-DRP map Frankelbach topsoil sealing (error = lack in basic data).

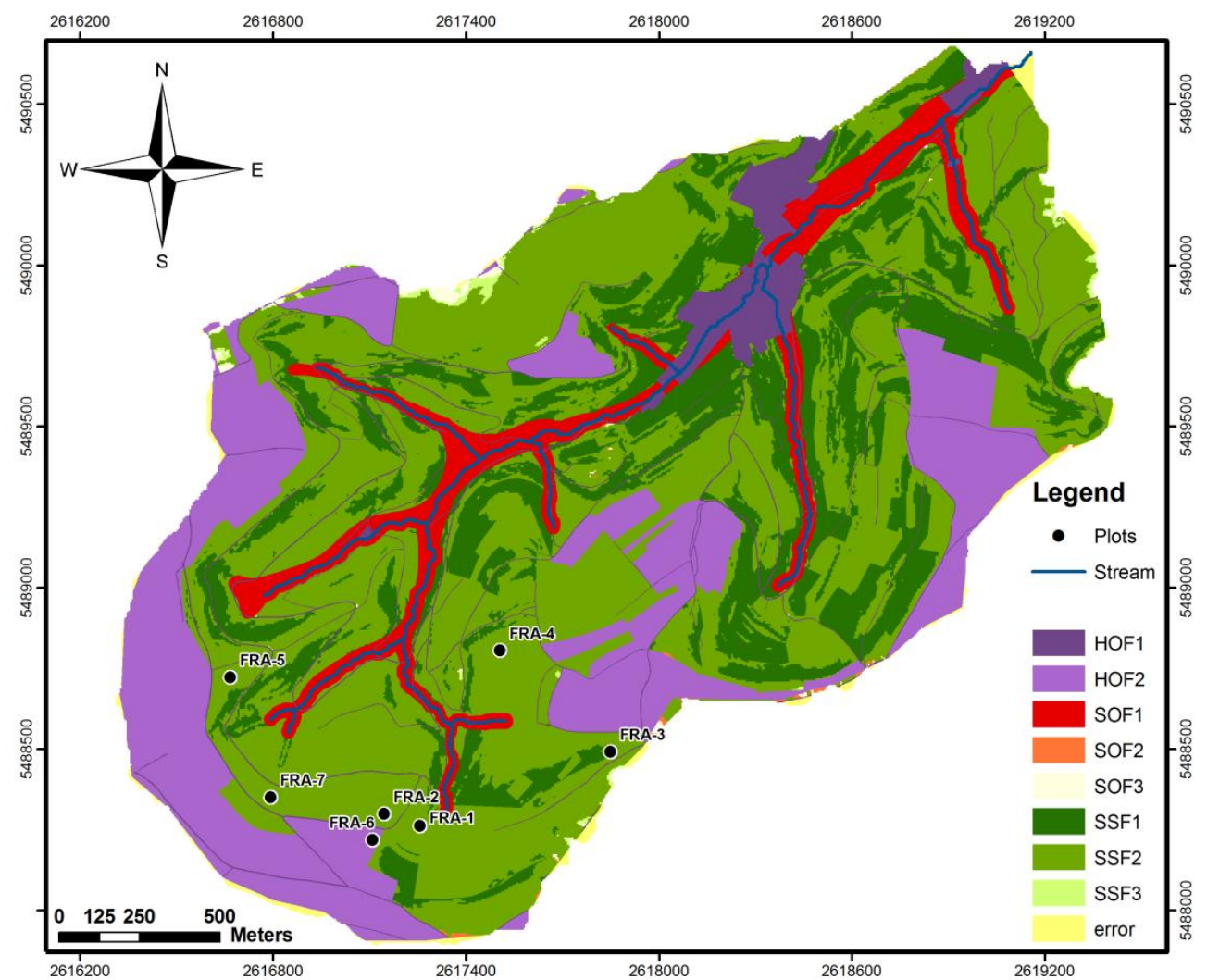

After this modification, the resulting GIS-DRP map as well as the Scherrer field-mapping and the soil-hydrological results of the field investigation provide a decent fit. Especially on test-plot FRA-6 
(acre), which was classified differently before the GIS-DRP improvement, the defined DRP is now adequate. Moreover, in comparison with a DRP-map based on the very detailed evaluation of the German Forest Site Survey (more information about this approach is given in [6]) the dominant runoff process of Hortonian overland flow at this plot is now adequate. Additionally, by comparing the main runoff processes (HOF, SOF, SSF and DP) of the modified GIS-DRP approach and the Forest Site Survey approach based on Schüler [6], an improvement from $78 \%$ to $89 \%$ total accuracy of defined DRP can be recorded. This means that an optimized spatial distribution of the different runoff processes as well as the identification of the process of topsoil sealing was assured. However, during a practical application of the improved GIS-DRP approach, it is of great importance to study adequately the soil sealing risk e.g., by using free available soil databases/maps.

\subsection{Extreme Event}

In case of the application of the new GIS-DRP extreme event approach, the process varieties generally change towards the faster reacting process variability; e.g., SSF 3 turns into SSF 2 or even SSF 1. Hence, fast reacting subsurface flow can also be found in forests as the dominating process during extreme rainstorm events (Table 5; Figure 11). Especially in forested areas with poor basic soil characteristics, like water logging or shallow soil depths (e.g., as found on plot FRA-2 (30 year-old afforestation)), fast reacting subsurface flow and even saturated overland flow can be estimated during intense precipitation [15].

Grassland predominantly reacts with varying processes of saturated overland flow during heavy rainfall (SOF 1 and SOF 2). In contrast to this estimation, several authors describe a very dense root tomentum occurring on grassland sites that has an inhibiting effect on the infiltration capacity e.g., $[23,34,35]$ and may therefore lead to Hortonian overland flow (HOF). The appearance of such root tomentum zones within grassland areas are very inhomogeneous in their temporal and spatial distribution and cannot be identified by the generalized basic data used for the GIS-DRP approach. This inhibits incorporation into the GIS-tool or its modification of root tomentum. Hence, no HOF processes on grassland can be determined with this method.

Areas with a disposition to soil sealing and crusting (mainly arable land) produce dominantly HOF 2 or even HOF 1 during rainstorm events, but this depends on the slope. Additionally, what becomes obvious by surveying the GIS-DRP map Frankelbach extreme event (Table 5) is that hot spots of discharge generation (areas of predominant surface runoff or concentrated runoff) can be determined: The area between plots FRA-2 and FRA-3 (grassland) generate saturated overland flow processes (SOF 2 and SOF 1) in case of an extreme weather event. The surface water connects directly to the perennial stream network. This could very well have been the cause for the repetitive flooding of the village of Frankelbach, which occurred in the years 1993, 1995 und 2002 [36]. 
Figure 11. GIS-DRP map Frankelbach extreme event (error = lack in basic data).

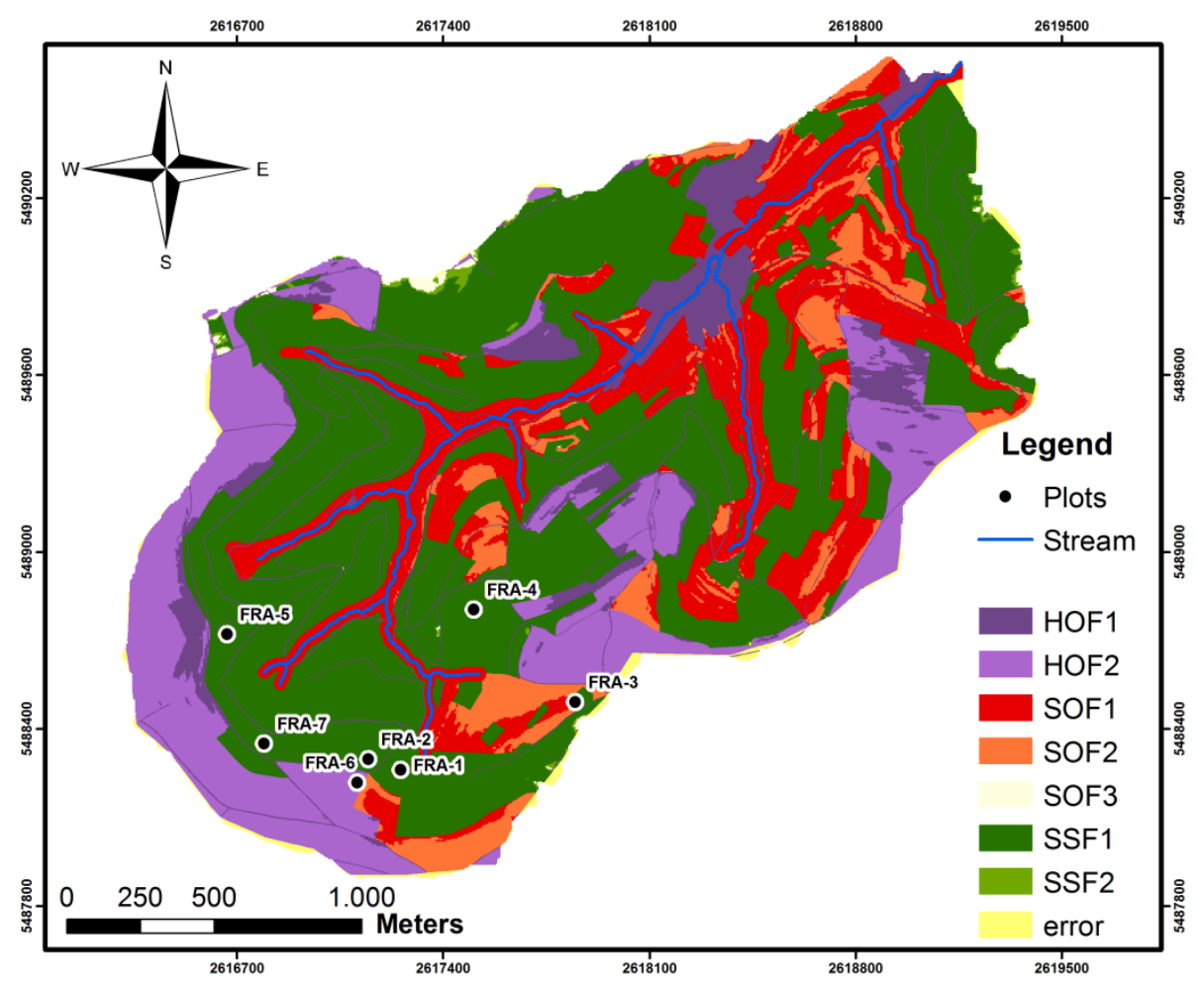

After appliance of GIS-DRP extreme event in the other investigated catchments, the runoff processes within the GIS-DRP maps predominantly change to their faster varieties (e.g., SSF 3 into SSF 2 or SSF 1). No major alternation of the process characteristic within one catchment could be observed. Since these catchments are mainly forested, subsurface flow processes are the predominant types of discharge except for the Huewelerbach in Luxembourg, which generates primarily deep percolation (DP) due to permeable parent material (Jurassic sandstone).

\subsection{Semipermeability}

The classification of the geological parent material of a specific area or catchment at this stage included the possibility of either choosing between the attributes "permeable" or "impermeable" within the basic GIS-DRP approach [20]. A permeable geologic material, like e.g., Jurassic sandstone (Li2) in the Huewelerbach catchment, therefore led mainly to deep percolation processes [37]. In contrast, a parent material classified as impermeable, such as Devonian schist, predominantly led to the identification of overland flow and subsurface flow processes, depending of course on the prevailing land use, slope and surface conditions.

However, soil-hydrological investigation in the Weierbach catchment showed that in certain cases this "black-or-white"-classification is insufficient. The results from the Holzbach catchment as well as the Weierbach test sites illustrated that large soil build-ups, a high gravel amount associated with a loose soil structure and periglacial cover layers build from blocky rock fragments demand a new class of permeability. Here, the infiltrating water will not be redirected into a lateral flow system due to impermeable layers, which is typical for periglacial cover layers that consist mostly of a porous main layer lying over a dense basal layer [38]. Furthermore, the water will be able to percolate into the 
underlying soil layers or the substratum, which has reduced water conductivity, but is not completely impermeable. The class stands in between the previous classes "permeable" and "impermeable" and it was named "semipermeable" in accordance with Zumstein et al. [21]. The mentioned attributes leading to "semipermeability" of the substratum are the precondition for generating so-called deeper subsurface flow (dSSF).

By implementing the parameter semipermeability and the dominant runoff process deeper subsurface flow (dSSF) into GIS-DRP, a precise reproduction of the DRP estimated in the Weierbach catchment was possible with the digital approach (Figure 12). Due to the small catchment size, the new map does not show many details in discharge generation. To illustrate the outcomes in a better way, the small Weierbach headwater catchment became embedded into the $258 \mathrm{~km}^{2}$ Attert catchment (Figure 13). This GIS-DRP semipermeability map shows on a meso-scale level that the permeability of the substratum and its spatial distribution has considerable effects on the result of the GIS-DRP approach.

Within the test site Holzbach, a more realistic coverage of the identified DRP was also reached with the optimized GIS method. Fifty percent of the plots are now characterized exactly, while the remaining $50 \%$ only differ by one class (HOL-2, HOL-3) or two classes (HOL-1), respectively, which is justifiable according to Scherrer [5].

Furthermore, it would be of great interest to implement these new findings of GIS-DRP into hydrological models. Hellebrand et al. [4] already indicated the need for an improvement of dominant runoff process identification and seasonality aspects to improve model performance when using GIS-DRP.

Figure 12. GIS-DRP-map Weierbach semipermeability.

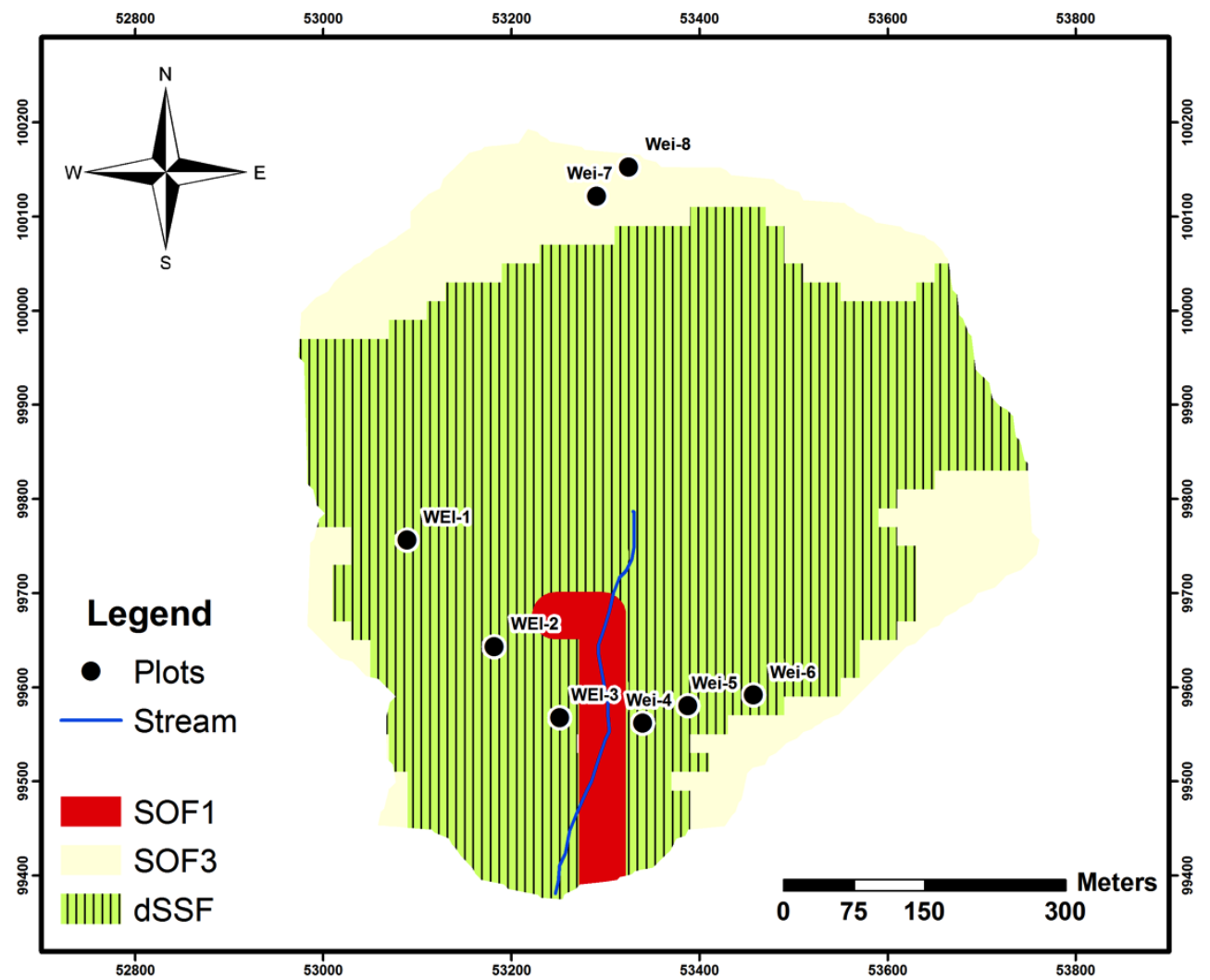


Figure 13. GIS-DRP-map Attert semipermeability (error = lack in basic data).

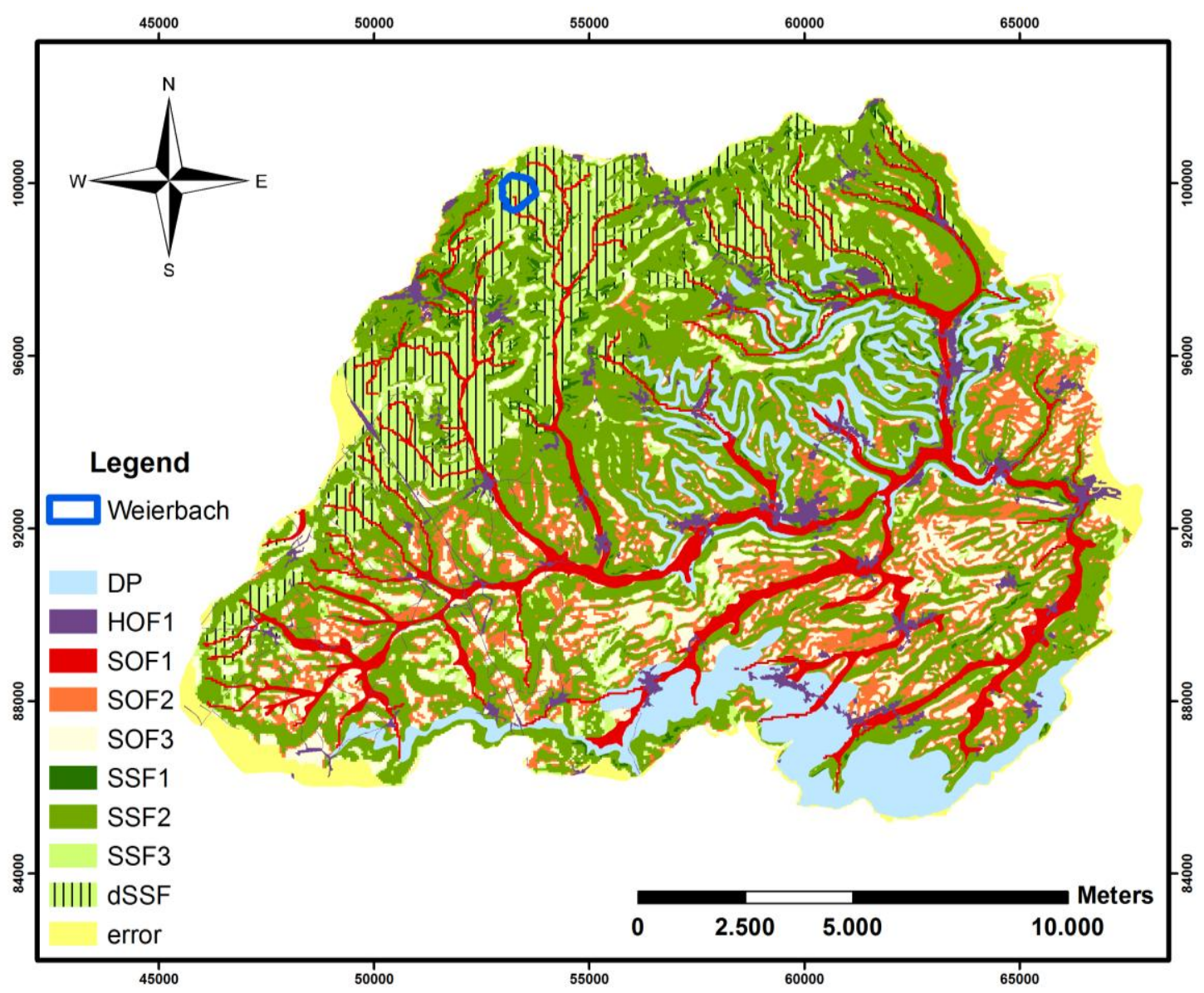

\section{Conclusion}

Maps of dominant runoff processes can be a helpful tool regarding the work of decision makers in land use management, forestry planning and stakeholders of several environment related fields of work. Digitally developed data, like the enhanced GIS-DRP maps, integrate expert knowledge in land use management concerning dominant runoff processes, discharge generation as well as landscape water balance. This information can be implemented directly within an active and sustainable planning.

The use of GIS-based maps makes it possible to define afforestation sites or identify hot spots of discharge generation. Afforestation measures can then be established to adverse runoff processes and in combination with amelioration measures like deep loosening, it is likely to enhance the water balance and runoff characteristics of determined areas. Moreover, flood precaution measures like retention basins, loosening measures or returning surface water back into the tree-stand can be applied at hot spots to reduce their negative influence on flood generation.

The above-mentioned advantages resulting from the implementation of the GIS-DRP tool in micro- and meso-scale catchments would generate positive effects concerning an appropriate forest planning and suitable management measures that also reflect a sustainable landscape water balance and an enhanced adaption of forests to drought or water stress situations. 


\section{Acknowledgments}

This study has received European Regional Development Funding through INTERREG IVB NWE (ForeStClim, www.forestclim.eu). The authors wish to thank the State office of geology and mining (LGB) Rhineland-Palatinate for providing basic data. We are grateful to the Forest Service Rhineland-Palatinate for the provision of the forest test sites and also to the tutors and students of the University Trier, who supported these investigations during field studies and laboratory work. The authors also would like to thank H. Hellebrand and A. Kaiser for fruitful discussions and helpful hints. We would like to thank the anonymous referees and the editor for their valuable comments.

\section{References}

1. Grigoryan, G.V.; Casper, M.C.; Gauer, J.; Vasconcelos, A.C.; Reiter, P.P. Impact of climate change on water balance of forest sites in Rhineland-Palatinate, Germany. Adv. Geosci. 2010, 27, $37-43$.

2. Casper, M.C.; Grigoryan, G.; Gronz, O.; Gutjahr, O.; Heinemann, G.; Ley, R.; Rock, A. Analysis of projected hydrological behavior of catchments based on signature indices. Hydrol. Earth Syst. Sci. 2012, 16, 409-421.

3. Intergovernmental Panel on Climate Change Ipcc. Klimaänderung 2007-Zusammenfassungen für politische Entscheidungsträger; Deutsche Übersetzung, Eds.; Deutsche IPCC-Koordinierungsstelle: Stuttgart, German, 2007.

4. Hellebrand, H.; Müller, C.; Fenicia, F.; Matgen, P.; Savenije, H. A process proof test for model concepts: modelling the meso-scale. Phys. Chem. Earth 2011, 36, 42-53.

5. Scherrer, S. Bestimmungsschlüssel zur Identifikation von Hochwasserrelevanten Flächen; Bericht 18; State Office for Water Economy Rhineland-Palatinate: Mainz, Germany, 2006; pp. 1-126.

6. Schüler, G. Identification of flood-generating forest areas and forestry measures for water retention. For. Snow Landscape Res. 2006, 80, 99-114.

7. Peschke, G.; Etzenberg, C.; Müller, G.; Töpfer, J.; Zimmermann, S. Das Wissensbasierte System FLAB - Ein Instrument zur rechnergestützten Bestimmung von Landschaftseinheiten mit gleicher Abflussbildung. IHI-Schriften 1999, 10, 122.

8. Scherrer, S.; Naef, F. A decision scheme to identify dominant flow processes at the plot scale for the evaluation of contributing areas at the catchments-scale. Hydrol. Process. 2003, 17, 391-401.

9. Scherrer, S.; Naef, F. A Decision Scheme to Identify Dominant Flow Processes at the Plot Scale for the Evaluation of Contributing Areas at the Catchments-Scale. In Runoff Generation and Implivations for River Basin Modelling; Leibundgut, C., Uhlenbrook, S., McDonnell, J., Eds.; Selbstverlag des Institutes für Hydrologie der Universität Freiburg: Freiburg, Germany, 2003; Volumen 13, pp. 11-16.

10. Schmocker-Fackel, P.; Naef, F.; Scherrer, S. Identifying runoff processes on the plot and catchment scale. Hydrol. Earth Syst. Sci. 2007, 11, 891-906.

11. Schobel, S. Erläuterungsbericht zur Abflussprozesskarte der Einzugsgebiete des Grundsgrabens und Schleidweiler Baches bei Gemeinde Zemmer/Eifel; Bericht Forschungsanstalt für Waldökologie und Forstwirtschaft Rheinland-Pfalz: Trippstadt, Germany, 2005; p. 76. 
12. Tilch, N.; Uhlenbrook, S.; Leibundgut, C. Regionalisierungsverfahren zur Ausweisung von Hydrotopen in von periglazialem Hangschutt geprägten Gebieten. Grundwasser 2002, 7 , 206-216.

13. Tilch, N.; Zillgens, B.; Uhlenbrook, S.; Leibundgut, Ch.; Kirnbauer, R.; Merz, B. GIS-gestützte Ausweisung von hydrologischen Umsatzräumen und Prozessen im Löhnersbach-Einzugsgebiet (Nördliche Grauwackenzone, Salzburger Land). Österreichische Wasser- und Abfallwirtschaft 2006, 58, 141-151.

14. Müller, C.; Hellebrand, H.; Seeger, M.; Schobel, S. Identification and regionalization of dominant runoff processes-A GIS-based and a statistical approach. Hydrol. Earth Syst. Sci. 2009, 13, 779-792.

15. Hümann, M.; Schüler, G.; Müller, C.; Schneider, R.; Johst, M.; Caspari, T. Identification of runoff processes-Impact of different forest types and soil properties on soil-water interrelations and floods. J. Hydrol. 2011, 409, 637-649.

16. Sauer, T. Modellierung von Bodenwasserhaushalt und Abflussprozessen auf der Plotskale in Abhängigkeit von Substrat und Landnutzung. Ph.D. Thesis, Universität Trier, Trier, Germany, 2009; p. 269.

17. Stahr, K. Die Bedeutung periglazialer Deckschichten für Bodenbildung und standortseigenschaften im Südschwarzwald. Freiburger Bodenkundliche Abhandlungen 1979, 9, 233.

18. Voelkel, J.; Zepp, H.; Kleber, A. Periglaziale deckschichten in mittelgebirgen-Ein offenes forschungsfeld. Berichte zur deutschen Landeskunde 2002, 76, 101-114.

19. Hellebrand, H. Theories, Experiments, Tools-An Applied Hydrologigal Spatio-Temporal Assessment of Meso-Scale Basins with a View to Regionalization. Ph.D. Thesis, TU Delft, Delft, The Netherlands, 2010.

20. Scherrer, S.; Demuth, N. Die Identifikation von Hochwasserrelevanten Flächen als Grundlage für die Beurteilung von Extremen Abflüssen. In Dezentraler Wasserrückhalt in der Landschaft durch vorbeugende Maßnahmen der Waldwirtschaft, der Landwirtschaft und im Siedlungswesen, Mitteilungen der FAWF; Schüler, G., Gellweiler, I., Seeling, S., Eds.; Forschungsanstalt für Waldökologie und Forstwirtschaft, 64/07: Trippstadt, Germany, 2007; pp. 175-182.

21. Zumstein, J.F.; Gille, E.; Deloux, J.P.; Paris, P. Atlas de la Lithologie et de la Perméabilité du Bassin Rhin-Meuse; Agence de l'eau Rhin-Meuse: Moulin-lès-Metz, France, 1989.

22. Müller, C. Hochwasserschutz in der Landwirtschaft_-Validierung und Modellierung Ausgewählter Maßnahmen. In Trierer Bodenkundliche Schriften; Emmerling, C., Eds.; Universität Trier: Trier, Germany, 2010; Band 15, p. 219.

23. Schobel, S. Infiltrations- und Bodenabflussprozesse in Abhängigkeit von Landnutzung und Substrat in der Trier-Bitburger Mulde. Ph.D. Thesis, Universität Trier, Trier, Germany, 2008.

24. Karl, J.; Toldrian, H. Eine transportable Beregnungsanlage für die Messung von Oberflächenabfluss und Bodenabtrag. Wasser und Boden 1973, 25, 63-65.

25. State Office for Water Economy Rhineland-Palatinate. Hochwasser im Rheineinzugsgebiet-März 2001; LFW-BERICHT NR. 204/01; Landesamt für Wasserwirtschaft: Mainz, Germany, 2001. 
26. Calvo, A.; Gisbert, J.M.; Palau, E.; Romero, M. Un simulador de Lluvia Portátil de Fácil Construcción. In Métodos y Técnicas Para la Medición en el Campo de Procesos Geomorfológicos; Sala, M., Gallart, F., Eds.; Sociedad Española de Geomorfología: Barcelona, Spain, 1988; pp. 6-15.

27. Lasanta, T.; Perez Rontome, M.C.; Garcia-Ruiz, J.M. Efectos Hidromorfológicos de Differentes Alternativas de Retirada de Tierras en Ambientes Semiáridos de la Depresión del Ebro. In Efectos Geomorfológicos del Abandono de Tierras; Lasanta, T., Garcia-Ruiz, J.M., Eds.; SEG: Zaragoza, Spain, 1994; pp. 69-82.

28. Iserloh, T.; Fister, W.; Ries, J.B.; Seeger, M. Design and Calibration of the Small Portable Rainfall Simulator of Trier University. In Proceedings of EGU General Assembly 2010, Vienna, Austria, 2-7 May 2010; p. 2769.

29. Wohlrab, B.; Ernsberger, H.; Meuser, A.; Sokollek, V. Landschaftswasserhaushalt. Wasserkreislauf und Gewässer im ländlichen Raum. Veränderungen durch Bodennutzung, Wasserbau und Kulturtechnik; Verlag Paul Parey: Hamburg und Berlin, Germany, 1992.

30. Tromp-van Meerveld, H.J.; McDonnell, J.J. Threshold relations in subsurface stormflow: 2. The fill and spill hypothesis. Water Resour. Res. 2006, doi: 10.1029/2004WR003800.

31. Schröder, R. Modellierung von Verschlämmung und Infiltration in landwirtschaftlich genutzten Einzugsgebieten; Asgard-Verlag: Sankt Augustin, Germany, 2000.

32. FAO. Soil Tillage in Africa: Needs and Challenges; FAO Soils Bulletin 69; Soil Resources, Management and Conservation Service Land and Water Development Division: Rome, Italy, 1993.

33. Schmidt, W.; Zimmerling, B. Nitzsche, O.; Krück, S.T. Conservation tillage-A new strategy in flood control. NATO Sci. Ser. 2001, 6, 287-293.

34. Markart, G.; Kohl, B.; Sotier, B.; Schauer, T.; Bunza, G.; Stern, R. Provisorische Geländeanleitung zur Abschätzung des Oberflächenbeiwertes auf alpinen Boden-/Vegetationseinheiten bei konvektiven Starkregen; BFW-Dokumentation; Bundesamt und Forschungszentrum für Wald: Wien, Österreich, 2004.

35. Sokollek, V. Untersuchungen über den Einfluß der Landnutzung auf den Oberflächenabfluss; Jahresbericht der ökologischen Forschungsstation Justus-Liebig-Universität Gießen: Gießen, Germany, 1977.

36. Johst, M. Experimentelle und Modellgestützte Untersuchungen zur Hochwasserentstehung im Nordpfälzer Bergland unter Verwendung Eines Neuartigen Spatial-TDR-Bodenfeuchtemessgeräts. Ph.D. Thesis, Universität Trier, Trier, Germany, 2011.

37. Juilleret, J.; Iffly, J.F.; Hoffmann, L.; Hissler, C. The potential of soil survey as a tool for surface geological mapping: A case study in a hydrological experimental catchment (Huewelerbach, Grand-Duchy of Luxembourg). Geologica Belgica 2012, 15, 36-41.

38. Chifflard, P.; Didszun, J.; Zepp, H. Skalenübergreifende prozess-studien zur abflussbildung in gebieten mit periglazialen deckschichten (Sauerland, Deutschland). Grundwasser 2008, 13, 27-41.

(C) 2013 by the authors; licensee MDPI, Basel, Switzerland. This article is an open access article distributed under the terms and conditions of the Creative Commons Attribution license (http://creativecommons.org/licenses/by/3.0/). 